\title{
Activation of Gonadotropin-Releasing Hormone Neurons by Kisspeptin as a Neuroendocrine Switch for the Onset of Puberty
}

\author{
Seong-Kyu Han, ${ }^{1}$ Michelle L. Gottsch, ${ }^{2}$ Kathy J. Lee, ${ }^{2}$ Simina M. Popa,${ }^{2}$ Jeremy T. Smith, ${ }^{2}$ Sonya K. Jakawich, ${ }^{2}$ \\ Donald K. Clifton, ${ }^{2}$ Robert A. Steiner, ${ }^{2}$ and Allan E. Herbison ${ }^{1}$ \\ ${ }^{1}$ Centre for Neuroendocrinology and Department of Physiology, University of Otago School of Medical Sciences, Dunedin, New Zealand, and ${ }^{2}$ Departments \\ of Obstetrics and Gynecology and Physiology and Biophysics, University of Washington, Seattle, Washington 98195-7290
}

\begin{abstract}
We examined the role of kisspeptin and its receptor, the G-protein-coupled receptor GPR54, in governing the onset of puberty in the mouse. In the adult male and female mouse, kisspeptin $(10-100 \mathrm{nM})$ evoked a remarkably potent, long-lasting depolarization of $>90 \%$ of gonadotropin-releasing hormone ( $\mathrm{GnRH}$ )- green fluorescent protein neurons in situ. In contrast, in juvenile [postnatal day 8 (P8) to P19] and prepubertal (P26-P33) male mice, kisspeptin activated only 27 and 44\% of GnRH neurons, respectively. This developmental recruitment of GnRH neurons into a kisspeptin-responsive pool was paralleled by an increase in the ability of centrally administered kisspeptin to evoke luteinizing hormone secretion in vivo. To learn more about the mechanisms through which kisspeptin-GPR54 signaling at the GnRH neuron may change over postnatal development, we performed quantitative in situ hybridization for kisspeptin and GPR54 transcripts. Approximately 90\% of GnRH neurons were found to express GPR54 mRNA in both juvenile and adult mice, without a detectable difference in the mRNA content between the age groups. In contrast, the expression of KiSS-1 mRNA increased dramatically across the transition from juvenile to adult life in the anteroventral periventricular nucleus (AVPV; $p<0.001$ ). These results demonstrate that kisspeptin exerts a potent depolarizing effect on the excitability of almost all adult GnRH neurons and that the responsiveness of GnRH neurons to kisspeptin increases over postnatal development. Together, these observations suggest that activation of GnRH neurons by kisspeptin at puberty reflects a dual process involving an increase in kisspeptin input from the AVPV and a post-transcriptional change in GPR54 signaling within the GnRH neuron.
\end{abstract}

Key words: GnRH; AVPV; GPR54; puberty; kisspeptin; hypothalamus

\section{Introduction}

Kisspeptins are neuropeptides encoded by the metastasis suppressor gene KiSS-1 and represent the natural ligands for the G-protein-coupled receptor GPR54 (Kotani et al., 2001; Muir et al., 2001; Ohtaki et al., 2001). Mutations in GPR54 are associated with sexual immaturity and infertility in humans (de Roux et al., 2003; Seminara et al., 2003; Semple et al., 2005), and this phenotype is mirrored in mice having genetically targeted deletions of GPR54 (Funes et al., 2003; Seminara et al., 2003). These findings suggest that kisspeptin-GPR54 signaling is critical for sexual maturation in humans and mice, but precisely how and where this signaling occurs and its relationship to puberty remain a mystery (Seminara and Kaiser, 2005).

The gonadotropin-releasing hormone $(\mathrm{GnRH})$ neuronal population serves as the final common pathway through which

\footnotetext{
Received Aug. 8, 2005; revised 0ct. 18, 2005; accepted 0ct. $27,2005$.

This work was supported by the Wellcome Trust and grants from the National Institutes of Health (R01 HD27142, SCCPRR-U54 HD12629, R01 DK61517).

Correspondence should be addressed to Allan E. Herbison, Centre for Neuroendocrinology, Department of Physiology, University of Otago School of Medical Sciences, P.0. Box 913, Dunedin, New Zealand. E-mail: allan.herbison@stonebow.otago.ac.nz.

DOI:10.1523/JNEUROSCI.3328-05.2005

Copyright $\odot 2005$ Society for Neuroscience $\quad$ 0270-6474/05/2511349-08\$15.00/0
}

the brain regulates the secretion of gonadotropins from the pituitary (Levine, 2003; Herbison, 2005). As such, the activation of $\mathrm{GnRH}$ neurons is the key event responsible for the initiation of puberty (Ojeda and Urbanski, 1994; Plant and Barker-Gibb, 2004). Thus, it seems plausible that kisspeptin-GPR54 signaling within the GnRH neuronal network is critical for the pubertal activation of GnRH neurons (Popa et al., 2005; Seminara and Kaiser, 2005), and the results of recent studies support this concept. For example, the central administration of kisspeptin into the brain produces an extraordinarily potent inductive effect on $\mathrm{GnRH}$ release and, consequently, luteinizing hormone (LH) and follicle-stimulating hormone secretion (Gottsch et al., 2004; Irwig et al., 2004; Messager et al., 2005; Navarro et al., 2005a,b). The site of kisspeptin-GPR54 signaling within the GnRH neuronal network is not conclusively established, but recent reports demonstrate expression of GPR54 mRNA in GnRH neurons of the fish (Parhar et al., 2004), rat (Irwig et al., 2004), and monkey (Shibata et al., 2005), suggesting that kisspeptin-expressing neurons directly innervate GnRH neurons. In the mouse, KiSS-1 mRNA-expressing neurons are found in the preoptic area, including the anteroventral periventricular nucleus (AVPV), periventricular nucleus $(\mathrm{PeN})$, and anterodorsal preoptic nucleus, and in the hypothalamic arcuate nucleus (Gottsch et al., 
2004). The presence of kisspeptin neurons in the AVPV is of particular interest, because neurons in this brain region are suspected of providing direct activational inputs to the GnRH neurons (Herbison, 1998; Simerly, 2002).

In the present study, we used patch-clamp electrophysiology, in situ hybridization, and in vivo experimental approaches to examine whether kisspeptin-GPR54 signaling at the GnRH neuron is developmentally regulated. Our results demonstrate a remarkably potent stimulatory effect of kisspeptin on the excitability of $\mathrm{GnRH}$ neurons and suggest a bimodal mechanism through which kisspeptin activates $\mathrm{GnRH}$ neurons at the time of puberty.

\section{Materials and Methods}

\section{Electrophysiology}

Male and female GnRH-EGFP-mut5 mice $(\mathrm{CBA} / \mathrm{Ca} \times \mathrm{C} 57 \mathrm{BL} / 6 \mathrm{~J})(\mathrm{Han}$ et al., 2004) were housed under $12 \mathrm{~h}$ light/dark cycles (lights on at 7:00 A.M.) with ad libitum access to food and water. All experimentation was approved by the University of Otago Animal Welfare and Ethics Committee. Three groups of male mice termed "juveniles" [postnatal day 8 (P8) to P19; $n=15$ ], "prepubertal" (P26-P33; $n=9$ ), and "adult" (older than P60; $n=10$ ) were used. Male GnRH-EGFP-mut5 mice become reproductively active around $\mathrm{P} 40$ in our colony, and to evaluate $\mathrm{GnRH}$ neurons across a range of time points leading up to puberty, we investigated mice at $2-3$ weeks of age (juvenile), well before puberty, and $\sim 1$ week before puberty (prepubertal group) and after puberty (adult). To examine potential sex differences in kisspeptin actions in adult mice, female mice (assessed by vaginal cytology) were examined on proestrus. Only one cell was recorded from each animal.

Gramicidin perforated-patch recordings of GnRH neurons were performed as reported previously in detail (Han et al., 2004). In brief, 200$\mu \mathrm{m}$-thick coronal slices containing the preoptic area were obtained from GnRH-EGFP-mut5 mice. Slices were viewed with a fixed-stage upright microscope (BX51WI; Olympus, Tokyo, Japan) and either fluorescence illumination or Nomarski differential interference contrast optics. Gramicidin (Sigma, Poole, UK) was dissolved in dimethylsulfoxide (Sigma) to a concentration of $2.5 \mathrm{mg} / \mathrm{ml}$, which was diluted in the pipette solution (in mM: $130 \mathrm{KCl}, 5 \mathrm{NaCl}, 0.4 \mathrm{CaCl}_{2}, 1 \mathrm{MgCl}_{2}, 10$ HEPES, 1.1 EGTA, $\mathrm{pH} 7.3$ ) to a final concentration of $2.5 \mu \mathrm{g} / \mathrm{ml}$ just before use, then sonicated for $15 \mathrm{~min}$. After cell attachment (4-7 M $\Omega$ patch electrode), access resistance was monitored, and experiments were begun when access resistance stabilized at 60-100 $\mathrm{M} \Omega$. Recordings were performed with a Multiclamp 700A (CV7B; Molecular Devices, Foster City, CA) and spontaneous activities sampled on-line with the use of a Digidata 1322A interface (Molecular Devices) connected to a personal computer. Signals were filtered ( $10 \mathrm{kHz}$; Bessel filter of Multiclamp 700A) before digitizing at a rate of $1 \mathrm{kHz}$. Acquisition and subsequent analysis of the acquired data were performed with the Clampex9 suite of software (Molecular Devices). Concentrations of 10 or $100 \mathrm{~nm}$ human kisspeptin-10 (amino acids 112-121; kindly provided by Drs. Stephanie Seminara and William F. Crowley Jr, Peptide Core Facility at the Massachusetts General Hospital, Boston, MA), with or without $0.5 \mu \mathrm{M}$ tetrodotoxin citrate (TTX; Tocris Cookson, Bristol, UK), was tested by addition to the oxygenated perifusing solution (in mM: $118 \mathrm{NaCl}, 3 \mathrm{KCl}, 2.5 \mathrm{CaCl}_{2}, 1.2 \mathrm{MgCl}_{2}, 11$ D-glucose, 10 HEPES, $25 \mathrm{NaHCO}_{3}$ ). Kisspeptin-10, which comprises the 10 amino acids at the $\mathrm{C}$ terminus of the full-length kisspeptin peptide, has the same potency as kisspeptin-52, the secreted peptide, in stimulating the GPR54 receptor in vitro (Muir et al., 2001) and in evoking LH secretion in vivo (Gottsch et al., 2004). Any cell that displayed a shift in resting membrane potential (RMP) of $>2.5 \mathrm{mV}$ or a change in firing rate $>25 \%$ was considered to have responded.

\section{In vivo studies}

Experiments were performed on adult and P18 male C57BL/6J mice housed and maintained under constant temperature and a $12 \mathrm{~h}$ light/ dark schedule (lights on at 6:00 A.M.). The P18 age group was used to enable comparisons with the juvenile P8-P19 mice used in electrophysiological experiments. Food and water were available ad libitum. All procedures were approved by the Animal Care Committee of the School of
Medicine at the University of Washington in accordance with the National Institutes of Health (NIH) Guide for Care and Use of Laboratory Animals. Kisspeptin-52 [KiSS-1 (68-119)-NH2 (mouse)/metastin (152)] was purchased from Phoenix Pharmaceutical (Belmont, CA). Freehand intracerebroventricular injections in the lateral cerebral ventricle were performed as described previously (Gottsch et al., 2004). Briefly, C57BL/6 mice were anesthetized with isoflurane (Abbott Laboratory, North Chicago, IL) delivered by a vaporizer (Veterinary Anesthesia Systems, Bend, OR). After achieving a surgical level of anesthesia, a small hole was bored in the skull $1 \mathrm{~mm}$ lateral and $0.5 \mathrm{~mm}$ posterior to bregma with a Hamilton syringe attached to a 27 gauge needle fitted with polyethylene tubing, leaving $3.5 \mathrm{~mm}$ ( $3.0 \mathrm{~mm}$ in P18 mice) of the needle tip exposed. Once the initial hole was made, all subsequent injections were made at the same site. Mice were allowed to recover for at least $2 \mathrm{~d}$ before treatment. For P18 mice, the holes for intracerebroventricular infusion were bored the day before the experiment (P17) while maintaining the animals under anesthesia. A heating pad was used to maintain normal body temperature during the surgical procedure and until awakening; then, the mice were returned to their mothers (after both injections). For intracerebroventricular injections, mice were anesthetized with isoflurane for a total of 2-3 min, during which time $2 \mu$ of solution was injected slowly into the lateral ventricle. The needle remained inserted for $\sim 60$ s after the injection to minimize backflow up the needle track. Mice typically recovered from the anesthesia within 3 min after the injection. Thirty minutes after the intracerebroventricular injection, the mice were placed under anesthesia once again, and blood was obtained via orbital bleed.

Serum LH concentrations were measured by Brigitte Mann at Northwestern University (Evanston, IL) with reagents obtained from the NIH (Chappel et al., 1997). The antiserum used was anti-rLH-S-11, and the standard was rLH-RP3. The assay sensitivity was $0.2 \mathrm{ng} / \mathrm{ml}$, and the intraassay coefficient of variation was $7 \%$.

\section{In situ hybridization experiments}

Adult male C57BL/6 mice $(n=6)$ were housed individually, whereas juvenile male mice $(n=7)$ were kept with their mothers until P18. All mice were housed and maintained under constant temperature and a $12 \mathrm{~h} \mathrm{light/dark} \mathrm{schedule} \mathrm{(lights} \mathrm{on} \mathrm{at} \mathrm{6:00} \mathrm{A.M.).} \mathrm{Food} \mathrm{and} \mathrm{water} \mathrm{were}$ available ad libitum. All procedures were approved by the Animal Care Committee of the School of Medicine at the University of Washington in accordance with the NIH Guide for Care and Use of Laboratory Animals. All animals were anesthetized with isoflurane and killed by decapitation. Brains were removed immediately from the calvaria and frozen on dry ice. Brains were stored at $-80^{\circ} \mathrm{C}$ and sectioned on a cryostat. Five sets of $20 \mu \mathrm{m}$ sections were collected from the rostral diagonal band of Broca to the caudal extent of the optic chiasm and stored at $-80^{\circ} \mathrm{C}$ until the time of the study. One set of tissue from each animal was removed from the freezer and processed.

Radiolabeled GPR54 cRNA riboprobe. Radiolabeled $\left({ }^{33} \mathrm{P}\right)$ antisense and sense mouse GPR54 probes were transcribed from the cDNA template as described previously (Irwig et al., 2004). The GPR54-specific sequence spanned bases 67-452 of the mouse cDNA sequence (GenBank accession number AF343726).

Digoxigenin-labeled GnRH cRNA riboprobe. The cDNA template for the GnRH riboprobe was generated with PCR primers designed to contain promoters for T7 RNA polymerase in the antisense direction or T3 RNA polymerase in the sense direction (antisense, CCAAGCTTCT AATACGACTC ACTATAGGGA GACTGCTGGG ATAAAAACGC TC; sense, CAGAGATGCA ATTAACCCTC ACTAAAGGGA GAATGGCCGG CATTCTACTG). The GnRH-specific primer sequences were based on genomic mouse sequence (chromosome 14) obtained by applying the basic local alignment search tool to the rat GnRH cDNA sequence (GenBank accession number NM012767) against the mouse genome. The PCR product was confirmed to be the mouse GnRH probe by sequencing. cDNA was transcribed for antisense riboprobes with T7 RNA polymerase plus in the presence of digoxigenin (DIG) labeling mix (Roche Products, Welwyn Garden City, UK) according to the manufacturer's protocol.

Radiolabeled KiSS-1 cRNA riboprobe. Antisense and sense mouse 
KiSS-1 riboprobes were generated as described previously (Gottsch et al., 2004). The kisspeptin-specific sequence spanned bases 76-486 of the mouse cDNA sequence (GenBank accession number AF472576).

Hybridization and development. Single-label (KiSS-1 mRNA) and double-label (GPR54 mRNA/GnRH mRNA) in situ hybridization was performed as described previously (Gottsch et al., 2004; Irwig et al., 2004). For single-label hybridization, radiolabeled antisense KiSS-1 riboprobe was denatured, diluted in hybridization buffer at a concentration of $0.03 \mathrm{pmol} / \mathrm{ml}$ along with yeast tRNA $(2 \mathrm{mg} / \mathrm{ml})$, and applied to slides (100 $\mu$ l per slide). After hybridization, slides were treated with RNase (32 $\mathrm{mg} / \mathrm{ml}$ ) and washed under conditions of increasing stringency. The slides were then dehydrated and dipped in Kodak (Rochester, NY) NTB emulsion, air-dried, and stored at $4^{\circ} \mathrm{C}$ until developed. For double-label hybridization, radiolabeled antisense GPR54 $(0.1 \mathrm{pmol} / \mathrm{ml})$ and DIGlabeled antisense $\mathrm{GnRH}$ riboprobes were denatured and combined in the same hybridization solution along with yeast tRNA $(1.9 \mathrm{mg} / \mathrm{ml})$. After hybridization, slides were treated and washed as above. GnRH mRNApositive cells were visualized using anti-DIG fragments conjugated to alkaline phosphatase (diluted 1:300; Roche Products) and Vector Red substrate (Vector Laboratories, Burlingame, CA) following the manufacturer's directions. The slides were dipped in 70\% ethanol and air-dried overnight. The slides were then dipped in Kodak NTB emulsion, airdried, and stored at $4^{\circ} \mathrm{C}$ until developed.

Slides were analyzed with an automated image processing system and custom grain-counting software, with identities of the individual slides unknown to the analyst. GnRH mRNA-containing cells were identified under fluorescent illumination by the presence of a fluorescent red stain, and the software was used to count the silver grains (corresponding to radiolabeled GPR54 mRNA) over each cell. Signal-to-background ratios (SBRs) for individual cells were calculated; a cell was considered to be double-labeled if it had an SBR $>3$. For each animal, the amount of double labeling was calculated as a percentage of the total number of GnRH mRNA-expressing cells and then averaged across animals to produce mean and SEM. For kisspeptin mRNA, the total number of cells per animal and the number of silver grains (corresponding to radiolabeled KiSS-1 mRNA) over each cell was examined.

\section{Statistical analysis}

For electrophysiological analyses, differences between adult males and females were assessed with nonparametric Mann-Whitney $U$ test, whereas differences between the developmental age groups were assessed with ANOVA or $\chi^{2}$ tests, as appropriate. For in vivo and in situ hybridization experiments, data are expressed as mean \pm SEM for each group. Variation among experimental groups was assessed by one-way ANOVA. When the ANOVA reached statistical significance $(p<0.05)$, differences among means were assessed by least significant difference tests. All analyses were performed with Statview 5.0.1 for Macintosh (SAS Institute, Cary, NC).

\section{Results}

Kisspeptin exerts a potent, long-lasting activational effect on adult GnRH neurons

Perforated-patch-clamp recordings were undertaken from identified green fluorescent protein (GFP)-tagged GnRH neurons located within the rostral preoptic area of acute brain slices. Recordings from GnRH neurons obtained from 10 adult (older than P60) male (Fig. 1) and five adult (proestrous) female (Fig. 2) mice revealed a remarkable, direct depolarizing effect of 10-100 nM kisspeptin-10 on the membrane potential of GnRH neurons. In adult males, 9 of $10 \mathrm{GnRH}$ neurons (mean RMP, $-60 \pm 2 \mathrm{mV}$ ) responded to a 1-3 min period of bath application of kisspeptin with an immediate and prolonged depolarizations (Fig. 1A,B). This was associated with an increase in firing in two cells (Fig. $1 A$ ), whereas another exhibited pronounced membrane oscillations in the presence of tetrodotoxin (Fig. $1 B$ ). The depolarizing effect of the 1-3 min of kisspeptin exposure was maintained for as long as the cell could be held, typically $\sim 30 \mathrm{~min}$, but in the case of

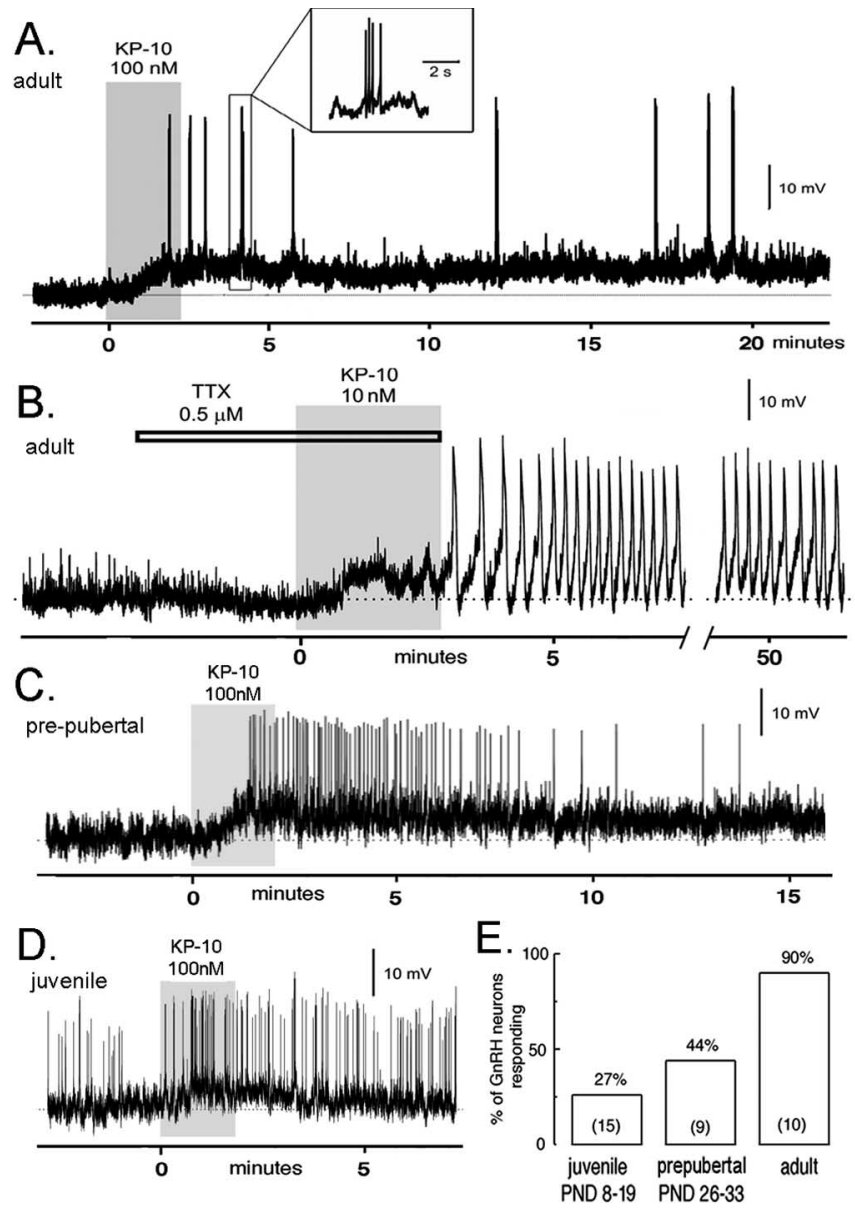

Figure 1. Kisspeptin exerts a potent, direct depolarizing action on GnRH neurons that is regulated developmentally. Perforated-patch, voltage recordings from GnRH-GFP neurons in the acute brain slice preparation of male mice. $A$, An adult male $\mathrm{GnRH}$ neuron (RMP, $-63 \mathrm{mV}$ ) is depolarized by $100 \mathrm{~nm}$ kisspeptin-10 (KP-10) for $>20$ min and exhibits short bursts of action potentials (inset). $\boldsymbol{B}$, Adult male $\mathrm{GnRH}$ neuron (RMP, $-60 \mathrm{mV}$ ) exhibiting a depolarizing response and pronounced membrane oscillations to $10 \mathrm{~nm}$ kisspeptin-10 (KP-10) in the presence of TTX. This cell continued to display membrane oscillations for $>50 \mathrm{~min}$ before the recording was lost. C, A prepubertal (P30; RMP, $-63 \mathrm{mV}$ ) GnRH neuron exhibiting a depolarizing response associated with increased firing in response to $100 \mathrm{~nm}$ kisspeptin-10 (KP-10). The depolarizing response in this cell lasted for $20 \mathrm{~min}$. D, Spontaneously active juvenile (P9; RMP, - 60 $\mathrm{mV}) \mathrm{GnRH}$ neuron responding to kisspeptin-10 (KP-10) with a transient depolarization. $\boldsymbol{E}$, Developmental recruitment of kisspeptin-sensitive $\mathrm{GnRH}$ neurons across puberty. The histogram shows the percentage of male juvenile (P8-P19), prepubertal (P26-P33), and adult (older than P60) GnRH neurons activated by KP-10 ( $n$ in parentheses). PND, Postnatal day.

two cells, the recordings lasted for $>60 \mathrm{~min}$ (Fig. $1 \mathrm{~B}$ ). The effects of kisspeptin on GnRH neurons persisted in the presence of tetrodotoxin $(n=3)$ (Fig. $1 B)$. Kisspeptin-10 had no effect on $\mathrm{GnRH}$ neurons recorded in whole-cell configuration $(n=3)$, indicating that the internal milieu of the GnRH neuron must be undisturbed for kisspeptin activation.

All five female GnRH neurons (RMP, $-66 \pm 5 \mathrm{mV}$ ) responded to a 1-3 min period of bath application of $10-100 \mathrm{nM}$ kisspeptin with an immediate and prolonged depolarization that was associated with intense firing (Fig. $2 A, B$ ). In all cases, the enhanced excitability including the enhanced firing rate was maintained for as long as the cell could be held in the perforatedpatch configuration. In one case, this was for $>80 \mathrm{~min}$.

In comparing the response of adult male and female $\mathrm{GnRH}$ neurons, the initial membrane depolarization induced by kisspeptin was larger in males $(7.3 \pm 0.6 \mathrm{mV})$ compared with 

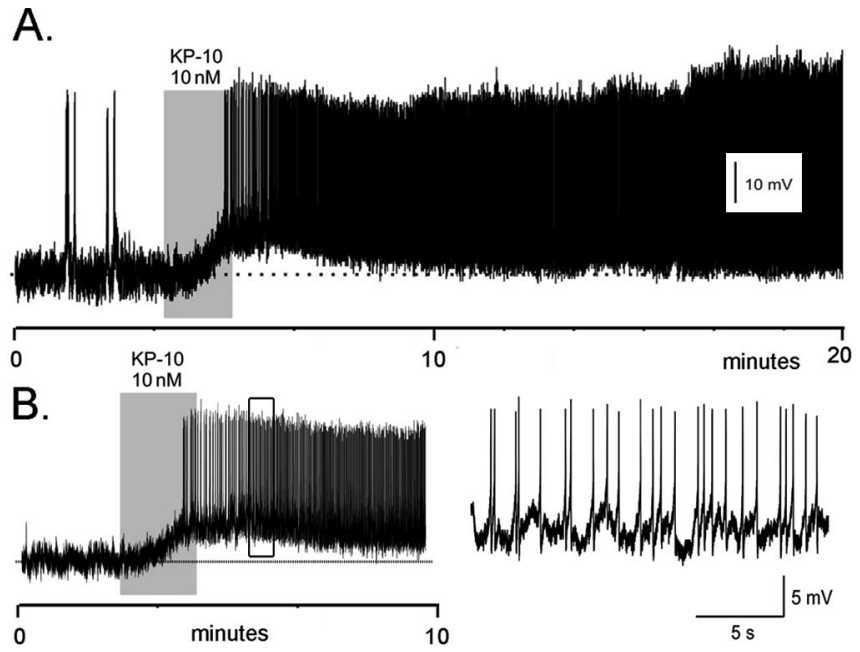

Figure 2. Kisspeptin exerts a potent activational effect on GnRH neurons in adult female proestrous mice. Perforated-patch, voltage recordings from proestrous female GnRH-GFP neurons in the acute brain slice demonstrate a remarkably intense and prolonged activation by 10 nm kisspeptin (KP-10). $\boldsymbol{A}$, Adult female $\mathrm{GnRH}$ neuron (RMP, $-75 \mathrm{mV}$ ) that was activated by KP-10 for $>80 \mathrm{~min}$, at which time the recording was lost. $\boldsymbol{B}$, Adult female GnRH neuron (RMP, $-68 \mathrm{mV}$ ) activated by KP-10. The firing pattern occurring within the open box is shown at an expanded time scale on the right.

females $(4.3 \pm 0.7 \mathrm{mV} ; p<0.05$; Mann-Whitney $U$ test $)$. However, whereas the kisspeptin-evoked depolarization was always associated with increased firing in GnRH neurons from females (five of five cells) (Fig. 2), the depolarization in male GnRH neurons was only associated with an increase in firing in two of nine cells (Fig. 1).

\section{GnRH neurons become responsive to kisspeptin across postnatal development}

We examined the responses of $\mathrm{GnRH}$ neurons from juvenile (P8-P19) and prepubertal (P26-P33) male GnRH-GFP mice to $100 \mathrm{~nm}$ kisspeptin-10. In prepubertal animals, four of nine (44\%) GnRH neurons (mean RMP, $-57.3 \pm 1.6 \mathrm{mV}$ ) displayed a depolarizing $(4.4 \pm 0.5 \mathrm{mV}$ ) response to $100 \mathrm{~nm}$ kisspeptin-10, and one of these exhibited an increase in firing rate (Fig. $1 C$ ). In contrast to adult mice, the longest period of depolarization evoked by kisspeptin was $\sim 20 \mathrm{~min}$ (Fig. $1 C$ ). In the youngest age group, 4 of $15(27 \%)$ juvenile GnRH neurons (RMP, - $57.2 \pm 1.5$ $\mathrm{mV}$ ) were depolarized by $100 \mathrm{~nm}$ kisspeptin-10 (mean depolarization, $6.6 \pm 1.5 \mathrm{mV}$ ) (Fig. $1 \mathrm{D}$ ), with one neuron showing a hyperpolarizing response and the remaining cells being unresponsive. None of the four depolarized GnRH neurons from juvenile mice exhibited any consistent increase in firing rate, and the depolarizing responses were all transient, lasting typically 2-3 $\min ($ Fig. 1D).

A significant increase $\left(p<0.01 ; \chi^{2}\right.$ test $)$ in the percentage of kisspeptin-responsive GnRH neurons was observed from juvenile $(27 \%)$ to prepubertal $(44 \%)$ to adult $(90 \%)$ male mice (Fig. $1 E)$. However, no differences were detected between adult, prepubertal, and juvenile GnRH neurons in terms of the initial degree of membrane depolarization evoked by kisspeptin (ANOVA). These results demonstrate that the GnRH neuronal population gradually acquires kisspeptin sensitivity over the course of postnatal development.

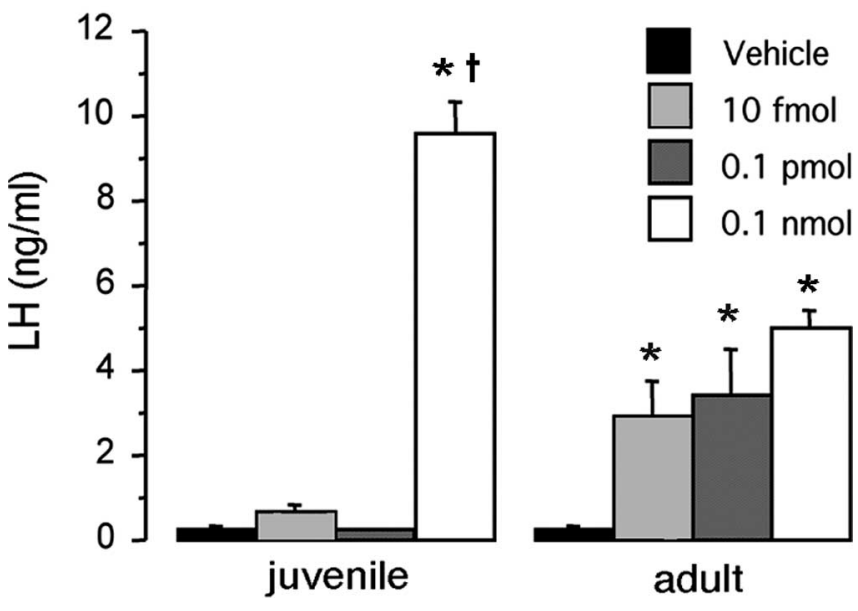

Figure 3. Developmental differences in the ability of kisspeptin to elicit LH release in vivo. Comparison of the LH response to kisspeptin- 52 between P18 and adult male mice. Various doses of kisspeptin were administered into the lateral cerebral ventricle of the brain (intracerebroventricularly) of P18 and adult male mice ( $n=6$ per group). Serum was collected 30 min later. ${ }^{*} p<0.01$ versus vehicle control; ${ }^{\dagger} p<0.001$ versus adult receiving $0.1 \mathrm{nmol}$. Error bars represent SEM.

\section{Kisspeptin stimulates LH secretion in a developmentally regulated manner in vivo}

To determine whether there is a developmental change in the responsiveness of $\mathrm{GnRH} / \mathrm{LH}$ secretion to kisspeptin administered in vivo, we examined the ability of different doses of intracerebroventricular kisspeptin-52 to evoke LH secretion in juvenile (P18) and adult male mice. As reported previously (Gottsch et al., 2004; Thompson et al., 2004; Navarro et al., 2005a), we found kisspeptin to be an extraordinarily potent activator of $\mathrm{LH}$ release in adult mice. In adults, kisspeptin-52 induced a marked and significant $(p<0.05)$ increase in serum levels of $\mathrm{LH}$ at all three doses tested (10 fmol, $0.1 \mathrm{pmol}$, and $0.1 \mathrm{nmol}$ ) (Fig. 3). In contrast, in juvenile mice, only the highest dose of kisspeptin ( 0.1 nmol) elicited an LH response (Fig. 3).

\section{The relative expression of GPR54 mRNA GnRH neurons is} similar in juveniles and adults

To assess whether the developmental increase in GnRH neuron responsiveness to kisspeptin might reflect an increase in the expression of GPR54 by GnRH neurons, we performed dual-label in situ hybridization experiments for GnRH and GPR54 transcripts in juvenile (P18) and adult male mice. The GnRH probe (labeled with Vector Red) revealed GnRH mRNA-expressing cells in their typical "inverted Y" distribution within the forebrain including the medial septum, diagonal band of Broca, and preoptic area. Sections hybridized with the GPR54 cRNA probe revealed clusters of ${ }^{33} \mathrm{P}$ silver grains over cells in the same areas. In juvenile male mice, $>90 \%$ of $\mathrm{GnRH}$ neurons, throughout their entire distribution, were found to be double labeled for GPR54 mRNA (Fig. 4A). An identical pattern of double-labeled cells was observed in GnRH neurons from adult male mice (Fig. $4 B$ ). No significant differences were detected in either the number of GnRH neurons coexpressing GPR54 or the relative expression of GPR54 mRNA in GnRH neurons between juvenile and adult male mice (Fig. $4 B$ ).

KiSS-1 mRNA in the AVPV is developmentally regulated In the AVPV, the number of identifiable cells expressing KiSS-1 mRNA was nearly sevenfold greater in adult compared with ju- 

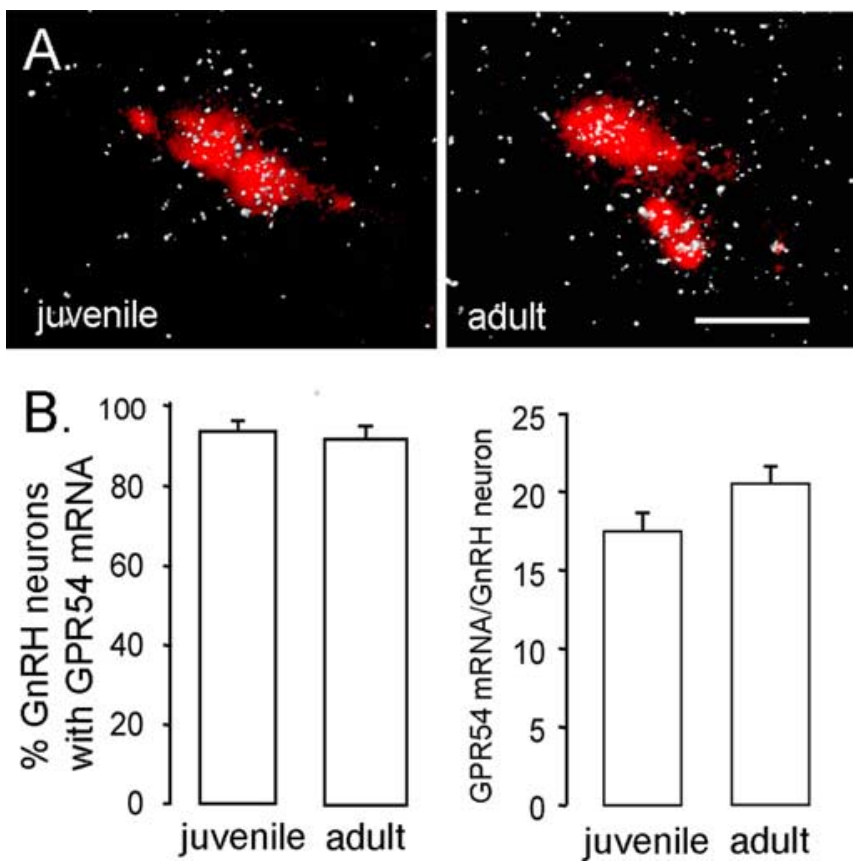

Figure 4. Expression of GPR54 mRNA in GnRH neurons across development. $\boldsymbol{A}$, Representative photomicrographs of cells coexpressing GPR54 mRNA (reflected by silver grains, appearing as clusters of white dots) and GnRH mRNA (labeled with Vector Red) in juvenile (left) and intact adult (right) male mice. Scale bar, $20 \mu \mathrm{m}$. B, Quantitative analysis of GPR54 mRNA in GnRH neurons demonstrated that neither the percentage of double-labeled cells (left) nor the relative expression of GPR54 mRNA in GnRH neurons (reflected by the number of silver grains per GnRH neuron; right) differed significantly between $\mathrm{P} 18$ and adult mice ( $n=6 / 7$ per group). Error bars represent SEM.

venile mice $(p<0.0001)$ (Fig. $5 A-C)$. The cellular content of KiSS-1 mRNA (as reflected by grains per cell) was also greater in adult compared with juvenile animals (1.5-fold increase; $p<$ 0.05 ) (Fig. 5D). A similar result was also seen in the PeN (data not shown). In the arcuate nucleus, the number of identifiable KiSS-1 mRNA-expressing cells was similar between juvenile and adult mice (Fig. 5E-G); however, the cellular content of kisspeptin mRNA was significantly less in the adults compared with the juveniles $(\sim 25 \%$ decrease; $p<0.001)$ (Fig. $5 H)$.

\section{Discussion}

We demonstrate here that kisspeptin is an extremely potent activator of nearly all GnRH neurons in the adult mouse. The persistence of the effects of kisspeptin in the presence of TTX and the identification of GPR54 transcripts in nearly all GnRH neurons argue that kisspeptin acts directly on GnRH neurons. There are several features of the kisspeptin response of adult GnRH neurons that are unique. First, the prolonged depolarizing response to just a short kisspeptin stimulus is remarkable and explains the curiously persistent effects of centrally administered kisspeptin observed on $\mathrm{GnRH}$ and gonadotropin secretion in vivo (Gottsch et al., 2004; Thompson et al., 2004; Messager et al., 2005; Navarro et al., 2005a; Shahab et al., 2005). Second, GnRH neurons display potent responses to low nanomolar concentrations of kisspeptin. This corroborates the extraordinarily potent effects of nanomolar to femtomolar doses of kisspeptin on gonadotropin secretion in vivo (Gottsch et al., 2004; Thompson et al., 2004; Navarro et al., 2005a). Third, GPR54 transcripts were identified in $90 \%$ of GnRH neurons, and kisspeptin was found to depolarize 14 of 15 (93\%) GnRH neurons in the adult. This is comparable with the
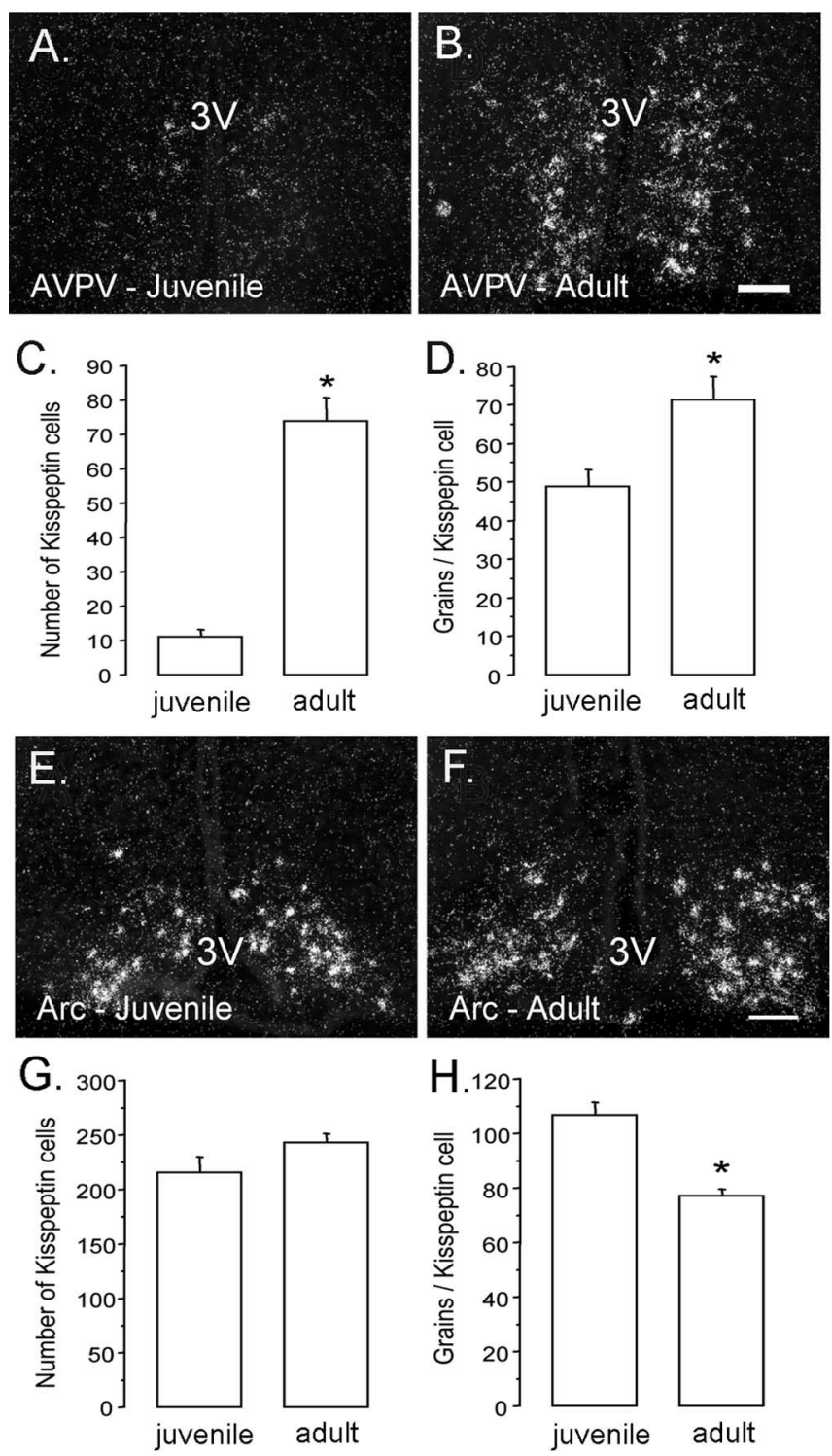

Figure 5. Developmental changes in KiSS-1 mRNA expression within the anteroventral periventricular and arcuate nuclei. $\boldsymbol{A}-\boldsymbol{D}, \mathrm{KiSS}-1 \mathrm{mRNA}$ in the AVPV. Photomicrographs show AVPV cells possessing KiSS-1 mRNA (reflected by silver grains, appearing as clusters of white dots) in juvenile (left) and adult (right) male mice. Quantitative analysis of kisspeptin mRNA revealed that both cell number $(\boldsymbol{C} ; p<0.0001)$ and cell content $(\boldsymbol{D} ; p<0.05)$ of kisspeptin mRNA increased significantly from juvenile to adult mice ( $n=6 / 7$ per group). $\boldsymbol{E}$, $\boldsymbol{F}$, KiSS-1 mRNA in the arcuate nucleus (Arc). Photomicrographs show KiSS-1 mRNA in the arcuate nucleus (Arc) of juvenile $(\boldsymbol{E})$ and adult $(\boldsymbol{F})$ male mice ( $n=6 / 7$ per group). Quantitative analysis of KiSS-1 mRNA in the Arc revealed that the number of positive cells did not differ between juvenile and adult mice (G); however, the per cell content of KiSS-1 mRNA (reflected by the number of silver grains per cell) was reduced in adult mice $(\boldsymbol{H} ; \boldsymbol{p}<0.001)$. The asterisks denote statistical significance. Scale bars, $100 \mu \mathrm{m}$. 3V, Third ventricle. Error bars represent SEM.

percentage of GnRH neurons showing Fos induction after kisspeptin treatment (intracerebroventricular) in the rat (Irwig et al., 2004; Matsui et al., 2004). This homogeneity of responsiveness is atypical for the GnRH neuronal phenotype and is only paralleled by the actions of glutamate in which all GnRH neurons express AMPA receptors (Spergel et al., 1999; Kuehl-Kovarik et al., 2002). However, the effects of AMPA receptor activation are not prolonged beyond the application period and also have only moderate efficacy in regulating GnRH neuronal excitability (Spergel et al., 1999; Kuehl-Kovarik et al., 2002; Suter, 2004). 
Hence, the present observations mark kisspeptin as the most potent excitatory stimulus to $\mathrm{GnRH}$ neurons discovered to date.

We also note that sex differences exist in the effects of kisspeptin on the excitability of adult GnRH neurons. Kisspeptin evoked a significantly larger membrane depolarization in GnRH neurons from males compared with females. However, this seldom increased firing rate in males, whereas the smaller depolarization always evoked a robust increase in firing rate from female $\mathrm{GnRH}$ neurons. Although the reasons for this are not known, it is important to note that the female GnRH neurons were examined on the afternoon of proestrus, at time at which they may be susceptible to fire in a continuous manner. Future studies will be required to evaluate the subcellular mechanism of the extraordinary actions of kisspeptin on GnRH neurons.

Collectively, the results of previous studies have suggested that kisspeptin and GPR54 are involved in the developmental activation of the GnRH neuronal network at puberty. Of foremost importance is the clear absence of puberty in the GPR54 knockout mouse (Seminara et al., 2003). Coupled with evidence that centrally administered kisspeptin activates GPR54 to stimulate gonadotropin secretion (Messager et al., 2005), these studies strongly implicate kisspeptin-GPR54 signaling events within the GnRH neuronal network as being necessary for puberty to proceed. In addition, developmental studies examining hypothalamic kisspeptin and GPR54 mRNA levels have found correlations between transcript expression levels and the onset of puberty in the rat (Navarro et al., 2004b) and monkey (Shahab et al., 2005). Also, gain-of-function studies have reported that exogenous kisspeptin administration can advance the onset of puberty in prepubertal female rats (Matsui et al., 2004; Navarro et al., 2004a). Hence, as a whole, these investigations have laid the foundation for the concept that kisspeptin-GPR54 signaling within the GnRH neuronal network may be a "gatekeeper" for puberty onset (Seminara and Kaiser, 2005).

We now provide evidence that kisspeptin-GPR54 signaling develops across puberty at the level of the GnRH neurons themselves. The percentage of GnRH neurons responding to kisspeptin increases from $\sim 25 \%$ in juveniles to $\sim 50 \%$ in prepubertal mice and to $>90 \%$ in adults, as does the duration of the depolarizing response. This pattern of development appears to be relevant in vivo, because the two lowest doses of intracerebroventricular kisspeptin were unable to stimulate LH release in juvenile male mice despite having robust stimulatory effects in adult males. Interestingly, we found that the highest dose of kisspeptin evoked a marked LH response in juvenile mice. This is consistent with studies in the prepubertal rat (Matsui et al., 2004; Navarro et al., 2004b) and juvenile monkey (Shahab et al., 2005), in which kisspeptin was shown to elevate $\mathrm{LH}$ secretion. This suggests that, despite their being only a relatively few $(\sim 25 \%)$ GnRH neurons that can respond to kisspeptin in juveniles, they are sufficient to drive the release of LH if stimulated by kisspeptin. Studies in the primate have clearly demonstrated that a period of central restraint of LH secretion occurs shortly after birth and that this is then reversed to enable puberty to occur (Terasawa and Fernandez, 2001; Plant and Barker-Gibb, 2004). Whether the same phenomenon exists in mice is unknown, but it will be intriguing in future studies to examine the kisspeptin responses of neonatal GnRH neurons.

How might GnRH neurons become activated by kisspeptin in a developmentally regulated manner? One possibility would be that the expression of GPR54 in GnRH neurons is under developmental control. However, our double-labeling in situ hybridization studies did not support this hypothesis, because we ob- served that levels of GPR54 mRNA in GnRH neurons were nearly identical between juvenile and adult male mice. Recent studies show that GPR54 mRNA expression within GnRH neuroncontaining whole-brain regions changes with development in the rat and primate (Navarro et al., 2004a; Shahab et al., 2005). Although we cannot be sure whether species differences exist, our single-cell findings highlight the potential difficulties of extrapolating whole-brain region data to individual neuronal phenotypes. Our observations suggest that the developmental changes in GnRH neurons result from post-transcriptional alterations in GPR54 expression and/or changes in its signaling cascade within the GnRH neuron.

The localization of kisspeptin neurons in the AVPV is intriguing, because this region has been implicated directly in the activation of GnRH neurons involved in generating the preovulatory GnRH/LH surge (Herbison, 1998; Simerly, 2002). Tracing studies have indicated that subpopulations of neurons in the AVPV project directly to GnRH neurons (Gu and Simerly, 1997; Simonian et al., 1999) and that this pathway develops early in postnatal life (Polston and Simerly, 2004). Here, we show that there is a sevenfold increase in the number of identifiable KiSS-1 mRNAexpressing cells in the AVPV of adult male mice compared with juvenile animals. Whether the increase in KiSS-1 mRNAexpressing cells in the AVPV precedes puberty or results from steroid activation of these cells after puberty (Smith et al., 2005a,b) is not known. Nevertheless, this result suggests that AVPV afferents may release greater amounts of kisspeptin onto GnRH neurons with postnatal development. If so, this would provide a two-pronged mechanism for the pubertal activation of GnRH neurons, with both their innervation by kisspeptin neurons and GPR54 receptor coupling being regulated in a developmental manner. Given the potent effects of kisspeptin on GnRH neuron excitability, this would provide a powerful mechanism for GnRH neuronal activation.

Although the case for kisspeptin-GPR54 signaling in the initiation of puberty is strong, it should be noted that several other neurotransmitters have been equally strongly implicated in the control of the onset of puberty. For example, GABA, glutamate, and NPY are considered important candidates (Plant, 2001; Terasawa and Fernandez, 2001) alongside potential roles for glial-derived signaling molecules (Ojeda et al., 2003). Although deletions or manipulations of these molecules may delay puberty in mice (Gonzales et al., 2004; Prevot et al., 2005), to our knowledge, the GPR54 knock-out mouse is the only model in which the complete absence of puberty is manifest as an isolated phenotype. This suggests that kisspeptin-GPR54 is high in the hierarchy of components within the GnRH neuronal network critical for puberty onset. Nevertheless, kisspeptin is unlikely to act alone within the network, and an integration of the actions of kisspeptin with those of other elements will be required before a full understanding of the pubertal activation of $\mathrm{GnRH}$ neurons is achieved.

In summary, we report here that kisspeptin represents the most potent activator of the GnRH neurons yet discovered. We demonstrate that GnRH neurons become increasingly sensitive to kisspeptin over development, with $>90 \%$ of these cells attaining responsiveness to kisspeptin as adults. The cellular mechanisms underlying this phenomenon are unknown but do not appear to involve developmental changes in GPR54 gene transcription within the GnRH neurons. The changes in the responsiveness of GnRH neurons over development are mirrored by the ability of kisspeptin to induce gonadotropin secretion in vivo. We also show that the expression of KiSS-1 mRNA in the AVPV is 
induced with the onset of puberty, providing a potential mechanism of enhanced input from kisspeptin neurons at the time of puberty. GPR54 is indispensable for the initiation of puberty in humans and mice (Seminara et al., 2003), and the present findings suggest that peripubertal amplification of kisspeptin-GPR54 signaling at the GnRH neuron itself represents a key component in the initiation of this critical developmental event.

\section{References}

Chappel PE, Lydon JP, Conneely OM, O'Malley BT, Levine JE (1997) Endocrine defects in mice carrying a null mutation for the progesterton receptor gene. Endocrinology 138:4147-4152.

de Roux N, Genin E, Carel JC, Matsuda F, Chaussain JL, Milgrom E (2003) Hypogonadotropic hypogonadism due to loss of function of the KiSS1derived peptide receptor GPR54. Proc Natl Acad Sci USA 100:10972-10976.

Funes S, Hedrick JA, Vassileva G, Markowitz L, Abbondanzo S, Golovko A, Yang S, Monsma FJ, Gustafson EL (2003) The KiSS-1 receptor GPR54 is essential for the development of the murine reproductive system. Biochem Biophys Res Commun 312:1357-1363.

Gonzales C, Voirol MJ, Giacomini M, Gaillard RC, Pedrazzini T, Pralong FP (2004) The neuropeptide Y Y1 receptor mediates NPY-induced inhibition of the gonadotrope axis under poor metabolic conditions. FASEB J $18: 137-139$

Gottsch ML, Cunningham MJ, Smith JT, Popa SM, Acohido BV, Crowley WF, Seminara S, Clifton DK, Steiner RA (2004) A role for kisspeptins in the regulation of gonadotropin secretion in the mouse. Endocrinology 145:4073-4077.

Gu GB, Simerly RB (1997) Projections of the sexually dimorphic anteroventral periventricular nucleus in the female rat. J Comp Neurol 384:142-164.

Han SK, Todman MG, Herbison AE (2004) Endogenous GABA release inhibits the firing of adult gonadotropin-releasing hormone neurons. Endocrinology 145:495-499.

Herbison AE (1998) Multimodal influence of estrogen upon gonadotropinreleasing hormone neurons. Endocr Rev 19:302-330.

Herbison AE (2005) Physiology of the GnRH neuronal network. In: Knobil and Neill's physiology of reproduction, Ed 3 (Neill JD, ed). San Diego: Elsevier.

Irwig MS, Fraley GS, Smith JT, Acohido BV, Popa SM, Cunningham MJ, Gottsch ML, Clifton DK, Steiner RA (2004) Kisspeptin activation of gonadotropin releasing hormone neurons and regulation of KiSS-1 mRNA in the male rat. Neuroendocrinology 80:264-272.

Kotani M, Detheux M, Vandenbogaerde A, Communi D, Vanderwinden JM, Le Poul E, Brezillon S, Tyldesley R, Suarez-Huerta N, Vandeput F, Blanpain C, Schiffmann SN, Vassart G, Parmentier M (2001) The metastasis suppressor gene KiSS-1 encodes kisspeptins, the natural ligands of the orphan G protein-coupled receptor GPR54. J Biol Chem 276:34631-34636.

Kuehl-Kovarik MC, Pouliot WA, Halterman GL, Handa RJ, Dudek FE, Partin KM (2002) Episodic bursting activity and response to excitatory amino acids in acutely dissociated gonadotropin-releasing hormone neurons genetically targeted with green fluorescent protein. J Neurosci 22:2313-2322.

Levine JE (2003) Gonadotropin-releasing hormone (GnRH). In: Encyclopedia of hormones (Henry H, Norman A, eds), pp 157-165. San Diego: Academic.

Matsui H, Takatsu Y, Kumano S, Matsumoto H, Ohtaki T (2004) Peripheral administration of metastin induces marked gonadotropin release and ovulation in the rat. Biochem Biophys Res Commun 320:383-388.

Messager S, Chatzidaki EE, Ma D, Hendrick AG, Zahn D, Dixon J, Thresher RR, Malinge I, Lomet D, Carlton MB, Colledge WH, Caraty A, Aparicio SA (2005) Kisspeptin directly stimulates gonadotropin-releasing hormone release via G protein-coupled receptor 54. Proc Natl Acad Sci USA 102:1761-1766.

Muir AI, Chamberlain L, Elshourbagy NA, Michalovich D, Moore DJ, Calamari A, Szekeres PG, Sarau HM, Chambers JK, Murdock P, Steplewski K, Shabon U, Miller JE, Middleton SE, Darker JG, Larminie CG, Wilson S, Bergsma DJ, Emson P, Faull R, et al. (2001) AXOR12, a novel human G protein-coupled receptor, activated by the peptide KiSS-1. J Biol Chem 276:28969-28975.
Navarro VM, Castellano JM, Fernandez-Fernandez R, Barreiro ML, Roa J, Sanchez-Criado JE, Aguilar E, Dieguez C, Pinilla L, Tena-Sempere M (2004a) Developmental and hormonally regulated messenger ribonucleic acid expression of KiSS-1 and its putative receptor, GPR54, in rat hypothalamus and potent luteinizing hormone-releasing activity of KiSS-1 peptide. Endocrinology 145:4565-4574.

Navarro VM, Fernandez-Fernandez R, Castellano JM, Roa J, Mayen A, Barreiro ML, Gaytan F, Aguilar E, Pinilla L, Dieguez C, Tena-Sempere M (2004b) Advanced vaginal opening and precocious activation of the reproductive axis by KiSS-1 peptide, the endogenous ligand of GPR54. J Physiol (Lond) 561:379-386.

Navarro VM, Castellano JM, Fernandez-Fernandez R, Tovar S, Roa J, Mayen A, Nogueiras R, Vazquez MJ, Barreiro ML, Magni P, Aguilar E, Dieguez C, Pinilla L, Tena-Sempere M (2005a) Characterization of the potent luteinizing hormone-releasing activity of KiSS-1 peptide, the natural ligand of GPR54. Endocrinology 146:156-163.

Navarro VM, Castellano JM, Fernandez-Fernandez R, Tovar S, Roa J, Mayen A, Barreiro ML, Casanueva FF, Aguilar E, Dieguez C, Pinilla L, TenaSempere M (2005b) Effects of KiSS-1 peptide, the natural ligand of GPR54, on follicle-stimulating hormone secretion in the rat. Endocrinology 146:1689-1697.

Ohtaki T, Shintani Y, Honda S, Matsumoto H, Hori A, Kanehashi K, Terao Y, Kumano S, Takatsu Y, Masuda Y, Ishibashi Y, Watanabe T, Asada M, Yamada T, Suenaga M, Kitada C, Usuki S, Kurokawa T, Onda H, Nishimura O, et al. (2001) Metastasis suppressor gene KiSS-1 encodes peptide ligand of a G-protein-coupled receptor. Nature 411:613-617.

Ojeda SR, Urbanski HF (1994) Puberty in the rat. In: The physiology of reproduction, Ed 2 (Knobil E, Neill JD, eds), pp 363-407. New York: Raven.

Ojeda SR, Prevot V, Heger S, Lomniczi A, Dziedzic B, Mungenast A (2003) Glia-to-neuron signaling and the neuroendocrine control of female puberty. Ann Med 35:244-255.

Parhar IS, Ogawa S, Sakuma Y (2004) Laser-captured single digoxigeninlabeled neurons of gonadotropin-releasing hormone types reveal a novel $\mathrm{G}$ protein-coupled receptor (Gpr54) during maturation in cichlid fish. Endocrinology 145:3613-3618.

Plant TM (2001) Neurobiological bases underlying the control of the onset of puberty in the rhesus monkey: a representative higher primate. Front Neuroendocrinol 22:107-139.

Plant TM, Barker-Gibb ML (2004) Neurobiological mechanisms of puberty in higher primates. Hum Reprod Update 10:67-77.

Polston EK, Simerly RB (2004) Ontogeny of projections from the AVPV to GnRH neurons and GnRH neuronal activation. Soc Neurosci Abstr 30:758.6.

Popa SM, Clifton DK, Steiner RA (2005) A KiSS to remember. Trends Endocrinol Metab 16:249-250.

Prevot V, Lomniczi A, Corfas G, Ojeda SR (2005) erbB-1 and erbB-4 receptors act in concert to facilitate female sexual development and mature reproductive function. Endocrinology 146:1465-1472.

Seminara SB, Kaiser UB (2005) New gatekeepers of reproduction: GPR54 and its cognate ligand, KiSS-1. Endocrinology 146:1686-1688.

Seminara SB, Messager S, Chatzidaki EE, Thresher RR, Acierno Jr JS, Shagoury JK, Bo-Abbas Y, Kuohung W, Schwinof KM, Hendrick AG, Zahn D, Dixon J, Kaiser UB, Slaugenhaupt SA, Gusella JF, O’Rahilly S, Carlton MB, Crowley Jr WF, Aparicio SA, Colledge WH (2003) The GPR54 gene as a regulator of puberty. $\mathrm{N}$ Engl J Med 349:1614-1627.

Semple RK, Achermann JC, Ellery J, Farooqi IS, Karet FE, Stanhope RG, O'Rahilly S, Aparicio SA (2005) Two novel missense mutations in G protein-coupled receptor 54 in a patient with hypogonadotropic hypogonadism. J Clin Endocrinol Metab 90:1849-1855.

Shahab M, Mastronardi C, Seminara SB, Crowley WF, Ojeda SR, Plant TM (2005) Increased hypothalamic GPR54 signaling: a potential mechanism for initiation of puberty in primates. Proc Natl Acad Sci USA 102:2129-2134.

Shibata M, Gibbs RB, Shahab M, Plant TM (2005) GnRH neurons in peripubertal male rhesus monkey express GPR54: implication for the control of primate puberty. Paper presented at 87th Annual Meeting of the Endocrine Society, San Diego, CA, June.

Simerly RB (2002) Wired for reproduction: organization and development of sexually dimorphic circuits in the mammalian forebrain. Annu Rev Neurosci 25:507-536. 
Simonian SX, Spratt DP, Herbison AE (1999) Identification and characterization of estrogen receptor alpha-containing neurons projecting to the vicinity of the gonadotropin-releasing hormone perikarya in the rostral preoptic area of the rat. J Comp Neurol 411:346-358.

Smith JT, Dungan HM, Stoll EA, Gottsch ML, Braun RE, Eacker SM, Clifton DK, Steiner RA (2005a) Differential regulation of KiSS-1 mRNA expression by sex steroids in the brain of the male mouse. Endocrinology 146:2976-2984.

Smith JT, Cunningham MJ, Rissman EF, Clifton DK, Steiner RA (2005b) Regulation of Kiss1 gene expression in the brain of the female mouse. Endocrinology 146:3686-3692.

Spergel DJ, Kruth U, Hanley DF, Sprengel R, Seeburg PH (1999) GABA-and glutamate-activated channels in green fluorescent protein-tagged gonadotropin-releasing hormone neurone in transgenic mice. J Neurosci 19:2037-2050.

Suter KJ (2004) Control of firing by small ( S)-alpha-amino-3-hydroxy-5methyl-isoxazolepropionic acid-like inputs in hypothalamic gonadotropin releasing-hormone (GnRH) neurons. Neuroscience 128:443-450.

Terasawa E, Fernandez DL (2001) Neurobiological mechanisms of the onse of puberty in primates. Endocr Rev 22:111-151.

Thompson EL, Patterson M, Murphy KG, Smith KL, Dhillo WS, Todd JF Ghatei MA, Bloom SR (2004) Central and peripheral administration of kisspeptin-10 stimulates the hypothalamic-pituitary-gonadal axis. J Neuroendocrinol 16:850-858. 